\title{
Chemopreventive effect of Quercus infectoria galls on DMBA induced mouse skin tumorigenesis
}

\author{
S.I. Amedi ${ }^{1}$ and B.M. Mohammad ${ }^{2}$ (D) \\ ${ }^{1}$ Department of Pathology and Microbiology, College of Veterinary Medicine, ${ }^{2}$ Department of Biology, College of Science, \\ University of Duhok, Duhok, Iraq
}

\section{Article information}

\section{Article history:}

Received November 12, 2019

Accepted December 8, 2019

Available online September 7, 2020

\section{Keywords:}

Skin carcinogenesis

Chemoprevention

Antioxidants

Histopathological alterations

Quercus infectoria galls

\begin{abstract}
Chemoprevention is an important strategy to control the process of carcinogenesis and a number of plants with anti-cancer properties are being researched, some of which have shown promising results. Quercus infectoria galls is a well-known medicinal plant which has been used in medicine as larvicidal, anti-inflammatory, antibacterial, anti-fungal, antioxidant, and antidiabetic properties. The present study was carried out to evaluate the anti-tumor activity of the aqueous extract on the two stage process of skin carcinogenesis, consisting of initiation with a single topical application of a carcinogen 7, 12 dimethylbenz (a) anthracene (DMBA) followed by a promoter (croton oil) three times in a week were employed. A significant reduction in tumor incidence, tumor burden, tumor yield, and cumulative number of papilloma was observed, along with a significant increase in average latent period in mice treated orally with $2 \mathrm{gm} / \mathrm{kg}$ of Quercus infectoria galls extract as compared to the positive control group treated with DMBA plus croton oil administered. Furthermore, Histopathological alterations in the carcinogen-treated control animals were also observed in the form of epidermal hyperplasia, keratinized pearl formation, and acanthosis in skin and tumors, whereas these were found to be reduced significantly before and after galls extract oral administration. The results thus concluded that Quercus infectoria galls extract exhibits significant anti-tumor activity and may serve in future drug development programs for the cancer prevention of skin cancer.
\end{abstract}

DOI: 10.33899/ijvs.2019.126267.1281, C2021, College of Veterinary Medicine, University of Mosul.

This is an open access article under the CC BY 4.0 license (http://creativecommons.org/licenses/by/4.0/).

\section{Introduction}

Living organisms are daily subjected to physiological and environmental chemical substances; in both developing and developed countries, carcinogenic substances associated with environmental pollution are regarded as important lethal factors that are threatening the public health. DMBA is not excluded from the environmental pollutants and it is greatly found in smoke of different sources including cigarette and car exhaust (1). DMBA is a potent carcinogenic agent involved in different steps of cancer development including initiation and promotion stages, it has been widely used as a cancer inducing agent in oncology studies (2). Scientists found that DMBA binds to DNA in mouse skin a target tissue, through a 1.2,3,4-ring dihydrodiol epoxide which links to and ruin DNA, Oxidative stress caused by Reactive Oxygen Species (ROS) that are greatly produced during metabolism of DMBA also found to play roles in developing cancer of skin (3). DMBA increases mutation rates of keratinocytes in skin epidermis and causes changes within composition of the cellular membrane, inactivate detoxifying enzymes and interfere with signaling proteins of cells, affect cells metabolism and deteriorate proteins structure (4). These lead to uncontrolled growth of cutaneous cells into squamous cell carcinoma (SCC), which regarded as the second most common type of epidermal neoplasia, the recently detected cancer globally classified as the skin tumor and up to $80 \%$ of these cancers 
found to be resulted from solar ultraviolet radiation. Squamous cell carcinoma (SCC) found to be induced directly by ultraviolet light damage, besides other causes like papilloma viruses from animal and human origin, existing ulcer and wounds, burns and also in old scars (5).

Recently, herbal treatments have been extensively considered in controlling and treatment aspects of skin cancer. Accordingly, identification of anti-cancer promoting agents within the medicinal plants would be of great importance in controlling of pathogenesis of skin cancer (6). Traditional medicine has obviously used medicinal plants, thus, in the current study, a plant specifically, Quercus infectoria (QI) galls has been chosen due to the fact that the plant has been historically widely involved in herbal treatments, it had been used for inflammatory diseases and wound infections (7). Tannins (gallotannic acid) is predominant constituent of Quercus infectoria galls up to $50-70 \%$, the compound is well known for its properties as anti-oxidant, anti-mutant, and anticancer (8). Studies reported various medical values of Quercus infectoria galls as larvicidal (9), anti-inflammatory (10), antibacterial (11), anti-fungal (12), antioxidant (13), and antidiabetic (14). To the best of our knowledge, there aren't any animal studies on the effect of QIGE in the prevention of skin carcinogenesis.

Hence, the current study aimed to assess the effectiveness of homogenized extract of Quercus infectoria galls in modifying the carcinogenic process in mice by measuring tumor incidence, tumor diameter, accumulating number of tumor, tumor burden, tumor yield, latent period and examination the histopathological changes in the DMBA / croton induced tumors in mice skin before and after Quercus infectoria galls aqueous extract (QIGE) administration.

\section{Material and methods}

\section{Chemicals}

DMBA the initiator was supplied by from ACROS organics -Belgium, and croton oil (promoter) were procured from Alfa Aesar-USA. $100 \mathrm{mg}$ of DMBA dissolved in acetone $100 \mathrm{ml}$, and then $1 \mathrm{ml}$ of solution (single dose) applied on the shaved region of mouse skin. To give a solution of $1 \%$ dilution, croton oil was mixed in acetone. From local sources, other analytical grade chemicals were purchased.

\section{Plant material}

Healthy Mature galls of Quercus infectoria (Figure 1) was collected locally from Gara Mountain, Amedi, Duhok, Iraq in October 2017, the plant galls were thoroughly washed by tap water and at room temperature the galls were air-dried in doors. The plant is authenticated by the Professor Dr. Saliem E. Shahbaz an expert in College of
Agricultural Engineering Sciences, University of Duhok, Iraq.

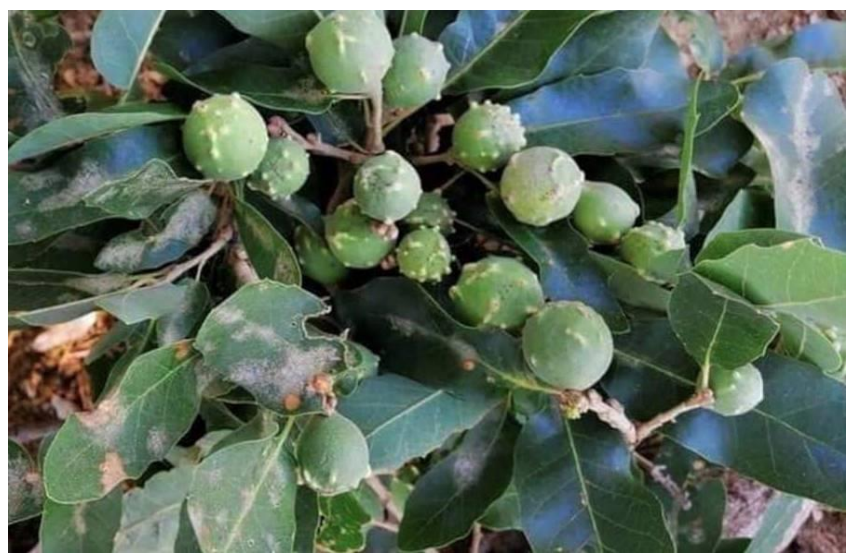

Figure 1: Quercus infectoria galls.

\section{Preparation of the homogenized Quercus infectoria galls}

Electric grinder was used to crush the cleaned galls into to a fine powder which was homogenized in distilled water for 24 hours. To prepared aqueous extract of plant, in distilled water $50 \mathrm{gm}$ of plant powder were suspended in Erlenmeyer flask and by magnetic stirrer the suspension was stirred over night at $45^{\circ} \mathrm{C}$. Following $24 \mathrm{~h}$, the precipitants were filtered firstly by using gauze and followed by filter papers, the filtration processes were repeated 5 times and before using rotary evaporator to dry the pooled extract under reduced pressure at $45^{\circ} \mathrm{C}(15)$. The obtained crude extract from the used powdered plant was weighted by the following formula; yield of extract $\%=$ weight of petri dish with extract - weight of empty Petri dish $150 * 100$. The crude extract then was stored in deep freezer at $-20^{\circ} \mathrm{C}$ to be used later. For the following experiments the extract was dissolved in PBS (solvent) to prepare the experimental doses of $2 \mathrm{gm} / \mathrm{kg}$ b.w.

\section{Experimental animals}

Random-breed male Swiss albino mice (Mus musculus), strain Balb/c (25-30 gm, 8-10 weeks) were obtained from University of Duhok, College of Science animal house. At standard laboratory conditions, the used animals in this study were kept in well controlled climate at temperature $22-26^{\circ} \mathrm{C}$, exposed to cycles of $12 \mathrm{~h}$ dark $/ 12 \mathrm{~h}$ light. The standard locally prepared diets were fed to mice with water ad libttum. Before starting of the experiment, the used mice were acclimatized for a week.

\section{Experimental design}

To test the chemopreventive efficacy of QIGE against skin papillomagenesis in mouse induced by DMBA and croton oil, 75 mature male mice used in this study were chosen at resting-growth phase from the inbred colony and 
grouped into seven different groups (Figure 2), the dorsal skin was carefully shaved $(2 \mathrm{~cm}$ diameter) by electric clipper to avoid injuries two days before application of the initiator. The groups were; group 1: Croton oil; $n=10$ : these animals were treated with $1 \mathrm{ml}$ of croton oil solution $(1 \mathrm{ml}$ croton oil/100 $\mathrm{ml}$ acetone) applied cutaneous to the shaven part in treated mice (3 times /week) over 16 weeks, group 2: Acetone; $n=5$ : animals of this group were injected with $1 \mathrm{ml}$ of an acetone on the dorsal clipped portion (3 times /week) over 16 weeks, group 3: DMBA (alone); $n=10$ : individual dose DMBA $(100 \mathrm{mg} / 100 \mathrm{ml}$ of acetone) was injected to the cleaned shaven skin area of the used animals and left without treatment for a period of 16 weeks, group 4: QIGE (-ve); n=5: animals were given Quercus infectoria galls extract orally $(2 \mathrm{gm} / \mathrm{kg}$. b.w. 3 times/week, following a period of 16 weeks, the treated rats were killed and their dorsal area of skin were taken for histopathological studies, group 5: DMBA+ Croton oil (+ve); $\mathrm{n}=15$ mice: an individual dose of DMBA (100 mg DMBA /100 ml of acetone) injected to the shaven area of the skin in treated animals., croton oil $1 \%$ ( $1 \mathrm{ml}$ croton oil $/ 100 \mathrm{ml}$ acetone) applied after 14 days of DMBA application. The treatment with croton oil was trice weekly and continued up to the sixteenth week at alternate days, group 6: Pre-Treatment; $\mathrm{n}=15$ mice: in this peri-initiation treatment group, animals were administered Quercus infectoria galls aqueous extract ( $2 \mathrm{gm} / \mathrm{kg}$ ) orally for 7 days, then DMBA solution single dose applied over the shaven part of skin, two weeks later mice were administered Quercus infectoria galls aqueous extract $2 \mathrm{gm} / \mathrm{kg}$ orally 3 times/week followed by applying $1 \%$ croton oil on the shaven part of the skin until the end of the experiment, group 7: Post-Treatment; $n=15$ : In this post-initiation treatment group, a single dose of DMBA solution applied topically to the shaven part of the mice skin, then after two weeks mice were administered Quercus infectoria galls aqueous extract $2 \mathrm{gm} / \mathrm{kg}$ orally 3 times/week followed by applying $1 \%$ croton oil on the shaven part continued to 16 weeks, modified from (16).

\section{In vivo determination of the chemo-modulatory effect of QIGE on skin carcinogenesis induced by DMBA/Croton oil}

To determine the in vivo chemo-modulatory efficacy of QIG on cancer development in skin by carcinogen DMBA/Croton oil, the listed parameters were applied.

\section{Morphological examination of tumor}

After the completion (i.e. 16 weeks) of the experiments, the considered parameters are: the tumors number in skin of individual mouse was reported. Skin papilloma were described as lesions $>1 \mathrm{~mm}$ in diameter and that were found minimally over two successive inspections (17). Tumor incidence: the number of affected mice with at least one lesion of skin cancer and referred as \% incidence. Tumor yield: The average number of papilloma / mice. Tumor burden: The average number of tumors / tumors bearing mouse. Cumulative number of tumors: the total number of tumors found in all mice. Tumor Diameter: The diameter of each tumor scaled by electronic caliper. Average latent period: the required time-lag for the appearance of $50 \%$ of tumors following using of the promoting agent was detected; the formula $\sum(F X / n)$ was used to determine the average latent period, which was determined by multiplying the tumors number observed per week by number of weeks following using promoting agent and divided by the total number of tumors. Where $\mathrm{F}$ is the reported numbers of tumors / week, X weeks numbers, and in the sum of tumors numbers. Measurement of body weight: The body weight of the individual animal was daily taken starting from the first date of the experiment and continued during the whole experiment time or was end by the animal death. Progressive increasing in body weight of the all mice groups was observed and recorded during treatment periods but their weight returned to nearly normal by the end of the experiment.

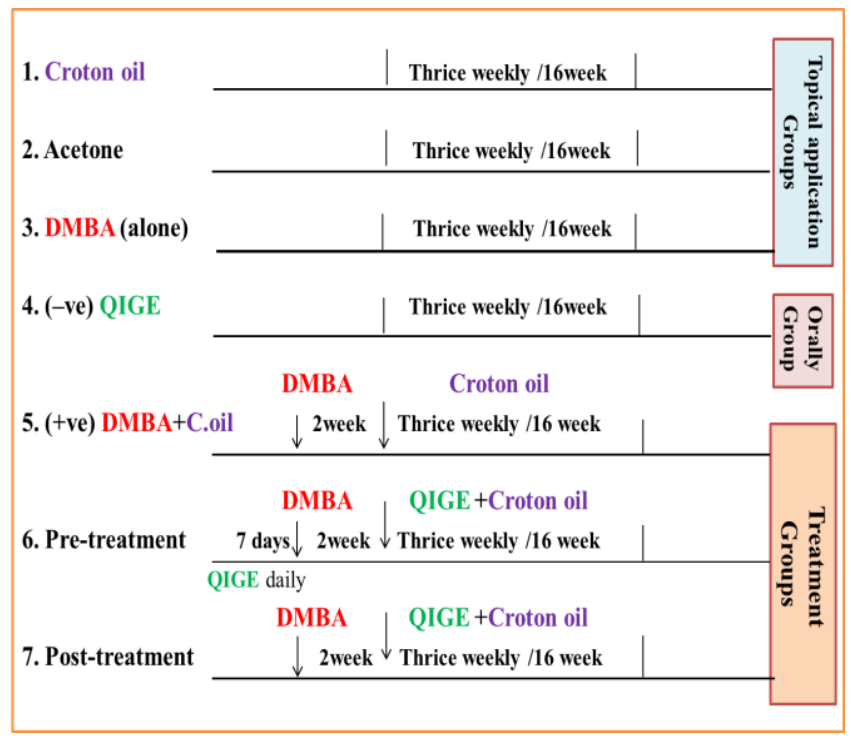

Figure 2: Dose application pattern in control and treatment groups.

\section{Histological evaluation}

For histopathological studies, skin tissues were taken from the affected part in treated rats; the taken tissues were fixed in $10 \%$ of formalin buffer solution then rinsed in water, a range of increasing concentration of ethanol $(70 \%$ $124 \mathrm{hrs}, 80 \% / 1 \mathrm{hr}, 90 \% / 1 \mathrm{hr}$ and $100 \%$ two exchanges, $1 \mathrm{hr}$ each) were used to dehydrate the tissues. Xylene was used for $10 \mathrm{~min}$ for twice to clear the samples. The samples were infiltrated in paraffin wax at $58^{\circ} \mathrm{Cin}$ oven for two exchanges 2 hours each. Paraffin block in the cassette were made for the samples which were cut into four parts before embedding the in wax. The embedded sections were cut at 
thickness of $4 \mu \mathrm{m}$ and then by hematoxylin and eosin (H\&E) stained following the staining protocol (18). The H\&E stained sections were examined microscopically using light microscope (Olympus VANOX-S Germany), images were taken by digital camera. The slides were evaluated by an expert pathologist who was blind to data. At least 10 fields per slide were examined and scored.

\section{Statistical analysis}

One-way analysis of variance (ANOVA) test was used to analysis the data of the present study. Duncan multiple range test was used to determine the specific variations between the groups and SPSS (V.23) was used to evaluated the results. $\mathrm{P}<0.05$ was the accepted significant level. Values were presented as mean \pm standard error of the mean (SEM) of 5-15 mice/group.

\section{Results}

Effect of QIGE on changes in body weight of mice

Progressive increases in the body weight of the treated mice after initial treatment were reported and such weight was found to show changes significantly in the body weight during the experimental protocol (Table 1).

\section{Effect of QIGE on morphological examination of tumor}

At 16th week of DMBA/Croton oil-treatment, the incidence of tumors developed papilloma (93\% incidence). The oral pre initiation treatment and post initiation treatment of QIGE at doses of $2 \mathrm{gm} / \mathrm{kg}$ significantly reduced the incidence of papilloma, and the recorded incidence in these groups was counted $0.40 \pm 0.131$ and $0.533 \pm 0.133$ respectively (Table 2 ).

Table 1: Variations in body weight during skin carcinogenesis induced by chemical in mice with or without Quercus infectoria galls aqueous extract

\begin{tabular}{lcc}
\hline \multirow{2}{*}{ Groups } & \multicolumn{2}{c}{ Body weight } \\
\cline { 2 - 3 } & Before treatment & After treatment \\
\hline Croton Oil (promoter) & $27.07 \pm 0.47^{\mathrm{A}}$ & $29.96 \pm 0.40^{\mathrm{B}}$ \\
Acetone (vehicle) & $27.54 \pm 0.6^{\mathrm{A}}$ & $30.73 \pm 0.73^{\mathrm{C}}$ \\
DMBA (initiator) & $27.46 \pm 0.30^{\mathrm{A}}$ & $30.98 \pm 0.32^{\mathrm{C}}$ \\
QIGE (- ve) & $28.05 \pm 0.47^{\mathrm{A}}$ & $30.26 \pm 0.72^{\mathrm{B}}$ \\
DMBA+ C. Oil (+ ve) & $29.89 \pm 0.38^{\mathrm{A}}$ & $33.50 \pm 0.70^{\mathrm{D}}$ \\
QIGE+DMBA+ C. Oil (Pre-treatment) & $28.63 \pm 0.61^{\mathrm{A}}$ & $31.02 \pm 0.56^{\mathrm{C}}$ \\
DMBA+ C. Oil + QIGE (Post- treatment) & $27.81 \pm 0.22^{\mathrm{A}}$ & $31.87 \pm 0.43^{\mathrm{D}}$ \\
\hline
\end{tabular}

The data were presented as mean \pm SEM ( $\mathrm{n}=5$-15). QIGE: Quercus infectoria galls aqueous extract; -ve: Negative control; DMBA: 7,12-Dimethylbenzanthracene; +ve: positive control. The different letters in the column referred to the significant differences at level $(\mathrm{P}<0.05)$.

Table 2: Effect of Quercus infectoria galls aqueous extract on morphological appearance of tumor

\begin{tabular}{lcccccc}
\hline $\begin{array}{l}\text { Parameters } \\
\text { group/Treatment }\end{array}$ & $\begin{array}{c}\text { Tumor } \\
\text { incidence }\end{array}$ & $\begin{array}{c}\text { Cumulative } \\
\text { Number of tumors }\end{array}$ & $\begin{array}{c}\text { Diameter } \\
\text { of tumors }\end{array}$ & $\begin{array}{c}\text { Tumor } \\
\text { Yield }\end{array}$ & $\begin{array}{c}\text { Tumor } \\
\text { Burden }\end{array}$ & $\begin{array}{c}\text { Average latent } \\
\text { Period (Weeks) }\end{array}$ \\
\hline Croton Oil (promoter) & 0.00 & 0.00 & 0.00 & 0.00 & 0.00 & 0.00 \\
Acetone (vehicle) & 0.00 & 0.00 & 0.00 & 0.00 & 0.00 & 0.00 \\
DMBA (initiator) & 0.00 & 0.00 & 0.00 & 0.00 & 0.00 & 0.00 \\
QIGE (+ve) & 0.00 & 0.00 & 0.00 & 0.00 & 0.00 & 0.00 \\
DMBA+ C. Oil (-ve) & $0.933 \pm 0.07^{\mathrm{A}}$ & $3.07 \pm 0.69^{\mathrm{A}}$ & $2.16 \pm 0.32^{\mathrm{B}}$ & $3.04 \pm 0.02^{\mathrm{A}}$ & $3.81 \pm 0.02^{\mathrm{A}}$ & $7.3 \pm 0.03^{\mathrm{A}}$ \\
$\begin{array}{l}\text { QIGE+DMBA+ C. Oil } \\
\text { (Pre-treatment) }\end{array}$ & $0.40 \pm 0.131^{\mathrm{C}}$ & $0.92 \pm 0.21^{\mathrm{B}}$ & $1.67 \pm 0.34^{\mathrm{B}}$ & $0.83 \pm 0.01^{\mathrm{B}}$ & $1.20 \pm 0.01^{\mathrm{B}}$ & $12.3 \pm 0.003^{\mathrm{C}}$ \\
$\begin{array}{l}\text { DMBA+ C. Oil + QIGE } \\
\text { (Post- treatment) }\end{array}$ & $0.533 \pm 0.133^{\mathrm{B}}$ & $1.21 \pm 0.28^{\mathrm{B}}$ & $1.56 \pm 0.29^{\mathrm{B}}$ & $1.20 \pm 0.01^{\mathrm{C}}$ & $1.69 \pm 0.01^{\mathrm{C}}$ & $9.7 \pm 0.01^{\mathrm{B}}$ \\
\end{tabular}

The data were presented as mean \pm SEM ( $\mathrm{n}=5$-15). QIGE: Quercus infectoria galls aqueous extract; -ve: Negative control; DMBA: 7,12-Dimethylben(z) anthracene; +ve: positive control. The different letters in the column referred to the significant differences at level $(\mathrm{P}<0.05)$.

Oral administration of QIGE in group 6 (pre-initiation) and group 7 (Post-initiation) significantly reduced $(\mathrm{P}<0.05)$ the accumulating number of tumors (total number of papilloma until the finish of experiment) $0.92 \pm 0.21$ and $1.21 \pm 0.28$ respectively as compared to the positive control group5 (+ve) 3.07 \pm 0.69 (Table 2). Concerning the tumor diameter, the groups 6 and 7 did not show significant $(\mathrm{P}<0.05)$ decreasing in tumor dimeter in comparison to mice were treated with DMBA/Croton oil (Table 2). While the average latent period (the required for developing of 
$50 \%$ of tumors after application of the promoter) was considerably longer in group 6 (Peri-initiation) and 7 (Postinitiation) i.e. $12.3 \pm 0.003$ weeks and $9.7 \pm 0.01$ weeks, respectively, while it was found higher in treated control with the carcinogen (Group 5) i.e. $7.3 \pm 0.03$ weeks. Significant reductions in tumor yield and tumor burden were reported in the animals of group 6 and 7 to $0.83 \pm 0.01$, $1.20 \pm 0.01$ and $1.20 \pm 0.01,1.69 \pm 0.01$ respectively comparing with their positive groups. None of the mice from the group 1(croton oil), group 2, the vehicle-treated group (acetone alone), group 3 (DMBA alone), and group 4 (QIGE alone) developed tumors (Table 2). Moreover, redness and inflammation were observed in mice skin of treated groups $1,2,3$ and hair loss was observed in skin of group 1 and 2 while group 3 its hair falls partially, and group 4 its hair did not fall.
Figure 3: Histopathology observation in skin tissue of experimental animals: (A): croton oil treated mice group; (B): acetone (alone) group vehicle treated mice; (C): DMBA (alone) group; (D): QIGE (-ve control) group (2 $\mathrm{mg} / \mathrm{kg}) ; \quad(\mathrm{E})$. DMBA and croton oil (+ve control) group; (F): QIGE, DMBA and croton oil (pretreat.); (G): DMBA, croton oil and QIGE (posttreat.) group. Abbreviation: E, epidermis; D, dermis; HD, hypodermal; PC, pearls cells; iPC, initial pearls cells; KP, keratinized pearls; H, hyperkeratosis; DK, dyskeratosis; P, papilloma; iP, initial papilloma EC, epidermis cells; I, Inflammation; De, degenerative; N, Necrosis; TE, thick epidermis; sTE, slight thick epidermis; $t E$, thin epidermis, $\mathrm{h}$ : hemmoarge.
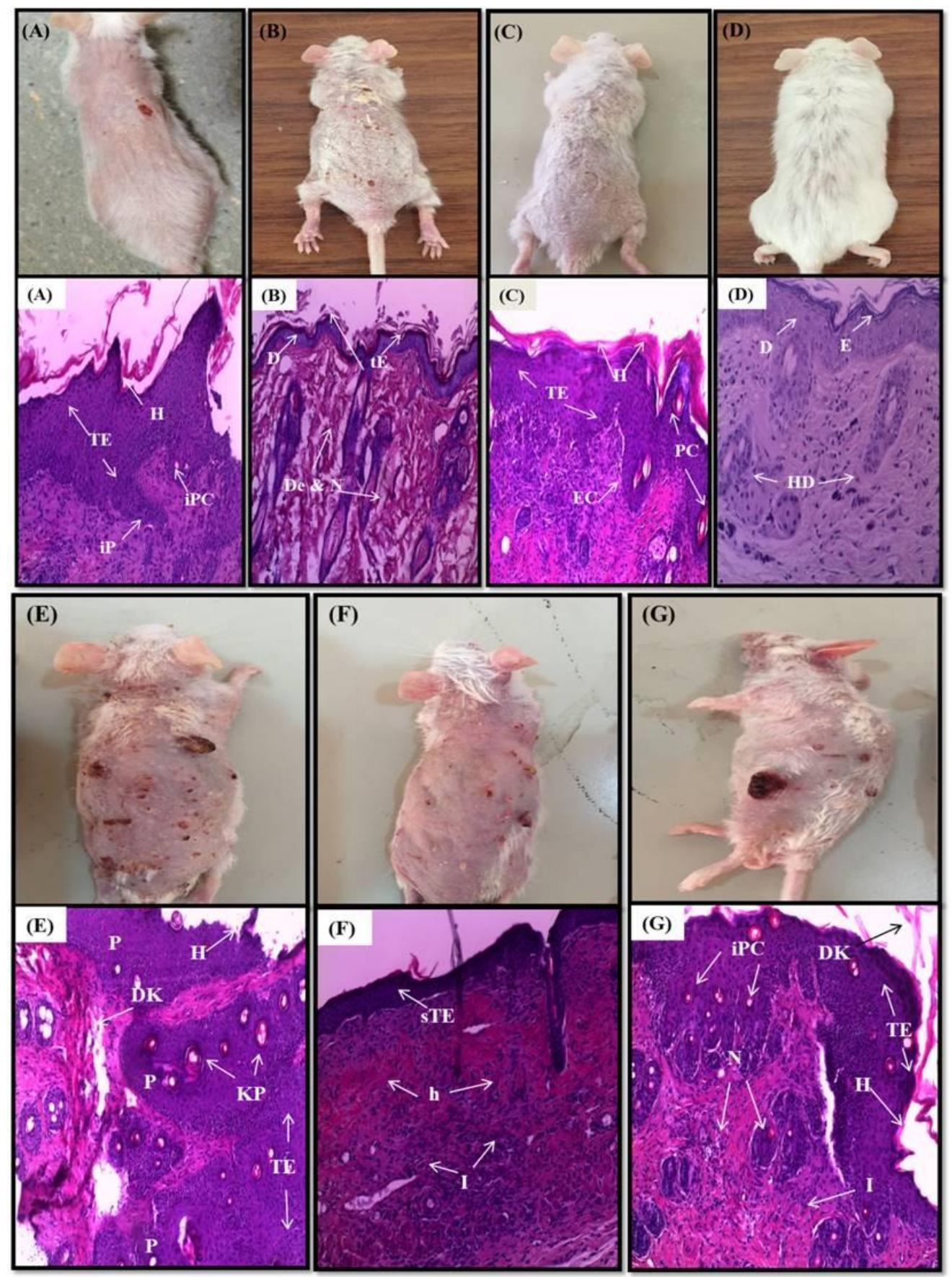


\section{Effect of QIGE on histopathology of skin}

In general, loose connective tissue and dense connective tissue made the dermal layer and referred as the papillary and reticular layers, respectively. Normal skin layers including epidermis, dermis, and hypodermal layer were observed intact and no changes were reported in the structure of the skin in mice groups were treated with QIGE (Figures 3-D). promoter treatment; croton oil (alone) group showed excessive thickening of epidermis layer, hyperkeratosis, initial formation of papilloma originated from epidermis, and initial formation of pearls cells (Figures 3-A). Acetone (alone) group: showed thin layer of epidermis, degenerative and necrotic changes of dermis and hypodermal layers (Figures 3-B). DMBA (alone) group found increases within the thickness of epidermal layer, hyperkeratosis, and infiltration of the dermis layer with epidermal cells and generation of new pearls cells (Figures 3-C). Treatment with carcinogenic agent and promoter induced occurrence of squamous cell carcinoma; dyskeratosis and hyperkeratosis of epidermis, abnormal thickening of epidermis, and deposition of keratinocytes pearls, deferent development of papilloma which originating from epidermis layer as a projection with excessive hyper-keratinization and invasion of epidermis cells into the dermis layer with necrosis and newly formation of blood vessels and tumor sections showed cells with abnormal nuclei (Figures 3-E). Treatment of the QIGE during the pre-initiation stage led to lower degree of epidermal hyperplasia, sever inflammation with hemorrhage in dermal and hypodermal layers (Figures 3-F). The slides in group7 (post-treat.) animals exhibited initial formation of pearls cells originated from epidermis with slight formation of papilloma, excessive thickening of epidermis layer which extend to dermal layer with infiltration of inflammatory cells and necrosis, hyperkeratosis, and dyskeratosis of epidermis (Figures 3G). The animals treated orally with QIGE at the dose of $2 \mathrm{gm} / \mathrm{kg}$ in group 6 (Figures F) and group 7 (Figures G) showed invasion of epidermal cells in the dermis and formation of keratinized pearls in comparison to the skin cancer induced in mice by DMBA/croton oil.

\section{Discussion}

Malignant neoplasia of skin is considered as one of the most common cause of the death in the world. 7-12 dimethylbenz [a] anthracene (DMBA) is a toxic pollutant within the environment and regarded as a potent skin carcinogenic agent (19). Different study models have been used to study pathogenesis of skin tumor, it is highly recommended to use murine model to study different stages of skin carcinoma development and to know the carcinogenesis of human epithelial cancers at molecular level (20). DMBA/Croton oil application was used to study the preclinical model of skin carcinogenesis in mice, the study included three chronological steps of cancer initiation (conversion/neoplasia), promotion (propagation/dysplasia or hyperplasia), and progression (metastatic). The primarily stage of carcinogenesis was indicated by the appearance of papilloma (21). ROS production was increased in animals exposed to DMBA and croton oil topically. DMBA indirectly acts as organ-specific carcinogenic agent, DMBA metabolism by CYP1A1 and CYP1B1 enzymes of CYP450 converts to a potent carcinogen 1,2-epoxide-3,4-diol. DMBA mutations in the genome found to be associated with the DMBA intermediate through forming DNA adducts serves as initiator in chemical carcinogenesis. Cellular proliferation and apoptosis occur by activation of protein-1 and NF- $\mathrm{kB}$ transcription factors, the factor is activated by transcription of early genes c-fos and c-jun as a result of binding the active constituent of croton oil 12-Otetradecanoyl phorbol-13-acetate with protein kinase C (22).

Frequent application of cancer promoting agent to the mouse skin locally generated nitric oxide (NO), reactive nitric oxide species, and ROS from Langerhans cells, polymorph nuclear leukocytes, and macrophage and nonphagocytic cells leading oxidative burst as well as inflammation of skin layers. In mutagenesis and carcinogenesis, ROS found to have important roles particularly in tumor promotion. ROS cause oxidative damage to almost all biomolecules such as lipids, DNA, RNA and proteins through changing various biochemical pathways and gene expression to leading to DNA strand break in turn play a crucial role in carcinogenesis $(3,22)$. Increasing attentions have been paid toward using of dietary non-nutrient compounds as chemopreventive agents, therefore, identification of local plants with natural bioactive compounds that could inhibit or stop cancer development is very important; recently, studies on murine models have greatly considered compounds with chemopreventive effects on cancer (23). Quercus infectoria galls is a cosmopolitan plant has been widely used in medicine as larvicidal (9), anti-inflammatory (10), antibacterial (11), anti-fungal (12), antioxidant (13), and antidiabetic (14). Moreover, in our previous study, we observed an antimutagenic potential of Quercus infectoria galls extract against DMBA induced bone marrow chromosome abnormalities in mice (24). and this study focused on the possible antitumor activity of the same galls extract and depending on genetic analysis, mutations could lead to cancer development and other chronic degenerative diseases such as atherosclerosis and other heart diseases (25). So, if the galls extract has the ability to inhibit DNA alternation, we may expect that it could prevent cancer or tumor development. However, the data of this research demonstrated that examination of mouse skin histopathologically after DMBA and croton oil application, showed great anomalies of cells such as changes within the 
epidermal layers, epithelium deterioration, cells necrosis, and focal proliferative area, infiltration of inflammatory cells in dermis and fluid accumulation within the epidermal cells were also reported. Likely, hematoxylin and eosin stained sections showed significant preventive effects of pre and post QIGE oral administration on DMBA and croton oil-induced changes in animal's skin. The data also found a reduction in incidence of tumor, total number of papilloma, tumor yield and tumor burden also resulted in significantly longer tumor latent periods, and general expected increase in body weight for all the experimental groups (Table 1), the total body weight showed similar weight gain in experimental and control mice, total daily caloric intake, growing in age might be the cause of weight gain. DMBA topically dose administration are thought to be at lower doses that cannot affect body weight, the protection from body weight loss in 4,6 and 7 treated groups, may be due to the presence of micronutrients, immunostimulant compounds, minerals and essential amino acids etc. in QIGE that makes healthy all the body systems and in turn increased the body weight of mice. QIGE contains immuno-enhancing (Gallic and ellagic acids: two natural immunomodulatory compounds), anti-inflammatory, antineoplastic, anti- microbial and anti-oxidants compounds that activate the immune system in order to induce apoptosis and suppress the proliferation and angiogenesis during the initiation and secondary modification stages of neoplastic development $(26,27)$. Besides, the data of the current study may detect that QIGE has significant bioantitmutagens and desmutagens potential against DMBAinitiated and croton oil-promoted skin tumorigenesis in mouse. Furthermore, (Table 2) show that skin papilloma in pre initiation treatment was more efficient in decreasing; tumor incidence and elongating of tumor latent periods; suggesting that the inhibition in the metabolism of DMBA to its active form and the delayed within the promotion phase of carcinogenesis was due to pretreatment with the galls extract, inhibition of croton oil-induced inflammatory responses, or downregulated reactive oxygen species formation, elevating various cellular antioxidants enzymes and reducing the oxidative damage caused by carcinogen and promoter (Desmutagens agent). While the significant modulation of the above morphological parameters in post initiation treatment may cause by the activation of repair enzymes, promoters of DNA repair, and agents that increase replication fidelity (Bio-antimutagen agent) (28).

The findings of this study ensure that QIGE act through multiple mechanisms to provide protection against DMBA mutagenicity and carcinogenicity. Such depletion of tumorigenesis might be owing to some active compounds existed in galls extract such as; tannins 50-70\%, gallic acid, ellagic acid, methyl gallate, $\beta$-sitosterol, 1,2,3,4,6-penta-Ogalloyl- $\beta$-D-glucose, amentoflavone, and purpurogallin which have been reported to present antioxidant, anticancer activities in either in vitro or in vivo studies $(8,26,29,30)$. ROS production was increased in animal exposed topically to DMBA and croton oil, evidences proved that antioxidant compounds protect DNA from the ROS damage and stop mutation $(31,32)$.

\section{Conclusion}

These findings suggest the strong anticarcinogenic potential of QIGE, Protective efficacy of the extract against DMBA induced genotoxicity and oxidative stress leading to carcinogenicity, especially when QIGE administrated at the pre-initiation stage of carcinogenesis and probably implicates the synergistic action of various antioxidants potential and free radical scavenging activity.

\section{Acknowledgement}

The authors gratefully acknowledge the Department of Biology, College of Science in Duhok for their support in providing their animal house laboratory and all its facilities to complete our practical work.

\section{Conflict of interest}

The authors declared no potential conflicts of interest with respect to the research, authorship, and/or publication of this article.

\section{References}

1. Lee LL, Lee JS, Waldman SD, Casper RF, Grynpas MD. Polycyclic aromatic hydrocarbons present in cigarette smoke cause bone loss in an ovariectomized rat model. Bone. 2002;30(6):917-923. Doi: 10.1016/s8756-3282(02)00726-3

2. Masaaki M, Masayuki F, Koichi T, Frank JG, Yasushi Y. Mechanism of 7,12-Dimethylbenz [a] anthracene - induced immunotoxicity: Role of metabolic activation at the target organ. Jpn J Pharmacol. 2001;86:302-309. Doi: 10.1254/jjp.86.302

3. Heather EK, Suryanarayana VV, Melissa JR, Ann U, John D. Role of cytochrome P450 1a1 and $1 \mathrm{~b} 1$ in the metabolic activation of 7,12dimethylbenz[a]anthracene and the effects of naturally occurring furanocoumarins on skin tumor initiation. Chem Res Toxicol. 2002;15(2):226-35. Doi: 10.1021/tx010151v

4. Marnett LJ, Riggins JN, West JD. Endogenous generation of reactive oxidants and electrophiles and their reactions with DNA and protein 2003. J Clin Invest. 111(5):583-593. Doi: 10.1172/JCI200318022

5. Shulstad, Raymond M.; Proper, Steven. Squamous Cell Carcinoma: A Review of Etiology, Pathogenesis, Treatment, and Variants. Journal of the Dermatology Nurses' Association. 2010;1(2):12-16. Doi: 10.1097/JDN.0b013e3181cb5165

6. Avni G, Desai GN, Qazi RK, Ganju ME, Jaswant S, Ajit K, Saxena YS, Bedi ST, Hari KBh. medicinal plants and cancer chemoprevention. Curr Drug Metab. 2008;9(7):581-591. Doi: $\underline{10.2174 / 138920008785821657}$

7. Umachigia SP, Jayaveerab KN, Ashok CK, GS Kumard, Vrushabendra BM, Kishore DV. Studies on wound healing properties of Quercus infectoria. Trop J Pharmaceut Res. 2008;7(1):913-919. Doi: 10.4314/tjpr.v7i1.14677 
8. Srivastava RC, Husain MM, Hasan SK, Athar M. Green tea polyphenols and tannic acid act as potent inhibitors of phorbol esterinduced nitric oxide generation in rat hepatocytes independent of their antioxidant properties. Cancer Letters. 2000;153(1-2):1-5. Doi: 10.1016/s0304-3835(99)00400-0

9. Redwane A, Lazrek HB, Bouallam S, Markouk M, Amarouch H, Jana M. Larvicidal activity of extracts from Quercus lusitania var. infectoria galls (Oliv.). J Ethnopharmacol. 2002;79(2):261-3. Doi: 10.1016/s0378-8741(01)00390-7

10. Kaur G, Hamid H, Ali A, Alam MS, Athar M. Anti-inflammatory evaluation of alcoholic extract of galls of Quercus infectoria. J Ethnopharmacol. 2004;90(2-3):285-92. doi: 10.1016/j.jep.2003.10.009

11. Basri D, Ha F. Antibacterial activity of the galls of Quercus infectoria. Sci. 2005;20(1):201-210. Doi: 10.4103/0253-7613.13851

12. Yamunarani $\mathrm{K}$, Jaganathan $\mathrm{R}$, Bhaskaran $\mathrm{R}$, Govindaraju $\mathrm{P}$, Velazhahan R. In vitro antifungal activity of a $29-\mathrm{kDa}$ glycoprotein purified from the galls of Quercus infectoria. Acta Phytopathol Entomol Hungarica. 2005;40(1-2):43-54. doi: 10.1556/APhyt.40.1-2.6

13. Kaur G, Athar M, Alam MS. Quercus infectoria galls possess antioxidant activity and abrogates oxidative stress-induced functional alterations in murine macrophages. Chem Biol Inter. 2008;171(3):272-82. Doi: 10.1016/i.cbi.2007.10.002

14. Saini R, Dev S. Anti-diabetic activity of roots of Quercus infectoria olivier in alloxan induced diabetic rats. Sci. 2012;3(4):1318-1321. Doi: 10.13040/IJPSR.0975-8232.3(5).1318-21

15. Yasser FM, Moath AN, Zena ST. Coumarins from creston apple seeds: Isolation, chemical modification, and cytotoxicity study. J Appl Pharm Sci. 2018;8(8):049-056. Doi: $10.7324 / J A P S .2018 .8808$

16. Sonam A. Chemoprotective effect of Tribulus terrestris on DMBA/croton oil mediated carcinogenic response. Acad J Cancer Res. 2015;8(1):18-27. Doi: 10.5829/idosi.ajcr.2015.8.1.91111

17. Lim TK. Edible medicinal and non-medicinal plants. New York: Springer; 2012. 158-162 p. Doi: 10.1007/978-94-007-7395-0

18. Lafta IJ, Alabbody HH. Incidence of cutaneous and subcutaneous tumors of dogs from Baghdad city: Clinical, cytological and histopathological features. Iraqi J Vet Sci. 2020;34(1):129-137. Doi: 10.33899/ijvs.2019.125624.1111

19. Morse MA, Stoner GD. Cancer chemoprevention principles and prospects. Carcinogenesis. 1993;14:1737-1746. Doi: 10.2307/3433309

20. Das I, Saha T. Effect of garlic on lipid peroxidation and antioxidation enzymes in DMBA-induced skin carcinoma. Nutrition. 2008;25(4):459-471. Doi: 10.1016/j.nut.2008.10.014

21. Irigaray P, Belpomme D. Basic properties and molecular mechanisms of exogenous chemical carcinogens. Carcinogenesis. 2010;31:135148. Doi: $10.1093 /$ carcin/bgp252

22. Das RK, Ghosh S, Sengupta A, Das S, Bhattacharya S. Inhibition of DMBA/croton oil-induced two-stage mouse skin carcinogenesis by diphenylmethyl selenocyanate. Euro J Cancer Prev. 2004;13(5):411417. Doi: $10.1097 / 00008469-200410000-00009$

23. Ebong PK, Atangwho IJ, Eyong EU, Egbung GE. The anti-diabetic efficacy of combined extracts from two continental plants: Azadirachta indica (A. juss) (Neem) and Vernonia amygdalina (Del.) (African bitter leaf). Am J Biochem Biotechnol. 2008;4:239-244. Doi: 10.3844/ajbbsp.2008.239.244

24. Amedi SI, Mohammed BMA. Anticlastogenic properties of Quercus infectoria galls extract against DMBA induced genotoxicity in bone marrow cells of mice in vivo. Iraqi J Vet Sci. 2020;34(2):279-285. Doi: 10.33899/ijvs.2019.125930.1188

25. S De Flora A, Izzotti K, Randerath E, Randerath H, Bartsch J, Nair R, Balansky F, van Schooten P, Degan G, Fronza D, Walsh J, Lewtas A. DNA adducts and chronic degenerative disease. Mut Res. 1996;366:197- 238 Doi: 10.1016/S0165-1110(96)00043-7

26. Asghar FY, Mansour D, Yahya M. In Vitro effect of methanolic extract of Quercus infectoria galls on promastigotes and amastigotes of leishmania major (MRHO/IR/75/ER). Med Lab J. 2018;12(5):1-6. Doi: $10.29252 / \mathrm{mlj} .12 .5 .23$

27. Seema P, Abdur R, Haroon K. The relevance of folkloric usage of plant galls as medicines: Finding the scientific rationale. Biomed Pharm. 2018;97:240-247. Doi: 10.1016/j.biopha.2017.10.111

28. Bronzetii G. Antimutagens in Foods. J Trends Food Sci Technol. 1994;5:390-395. Doi: 10.1016/0924-2244(94)90167-8

29. Ikram M, Nowshad F. Constituents of Quercus infectoria. Planta Med. 1977;31:286-287. Doi: $10.1055 / \mathrm{s}-0028-1097531$

30. Wiart C, Kumar A. Practical Handbook of pharmacognosy. Malaysia: Pearson Education Malaysia; 2001. 20-45 p. ISBN: 983-9236-64-4

31. Lee KW, Bode AM, Dong Z. Molecular targets of phytochemicals for cancer prevention. Nat Rev Cancer. 2011;11:211-218. Doi: 10.1038/nrc3017

32. Tian YF, Hsieh CH, Hsieh YJ, Chen YT, Peng YJ, Hsieh PS. $\alpha$-Lipoic acid prevents mild portal endotoxaemia-induced hepatic inflammation and $\beta$ cell dysfunction. Euro J Clin Invest. 2012;42:637-648. Doi: $\underline{10.1111 / \mathrm{j} .1365-2362.2011 .02630}$

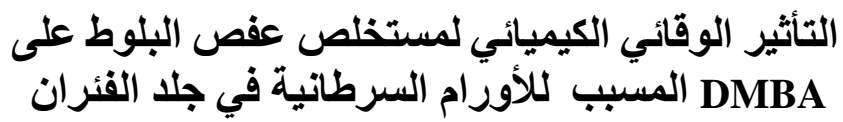

$$
\begin{aligned}
& \text { شيرزاد إبراهيم العمادي' و بشرى محمد أمين محمدץ }
\end{aligned}
$$

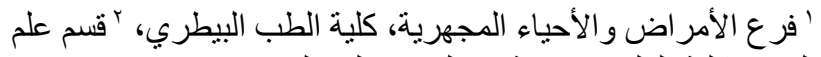

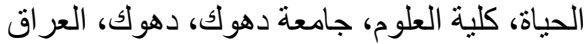

الخلاصة

الوقاية الكيماوية هي استراتيجية مهمة للسيطرة على عملية

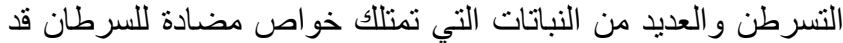

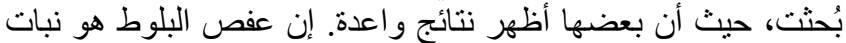
طبي معروف تم استخدامه في الطب لخصائصها المضادة المهادة للبكتيريا،

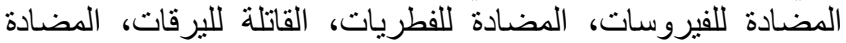

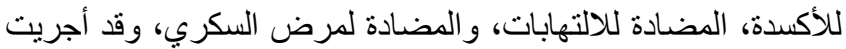

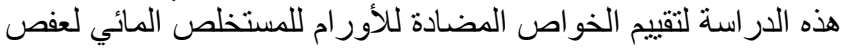

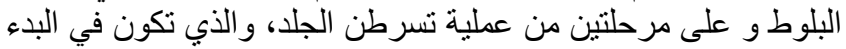

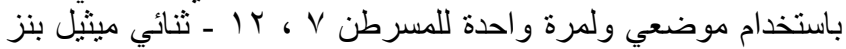

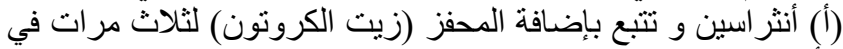

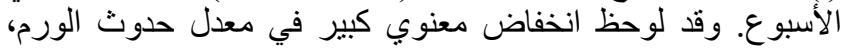

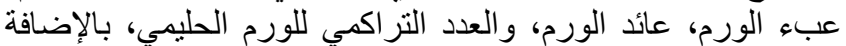

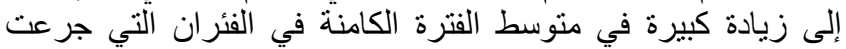

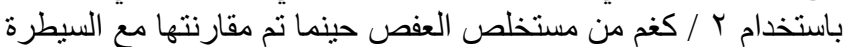

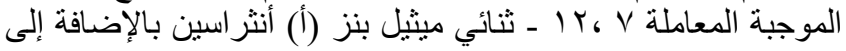

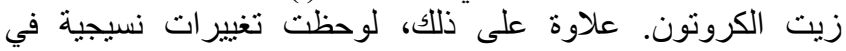
الحيوانات المعاملة و على شكل تضخم البشرة، تشكي تشكيل اللؤلؤة المتقرن،

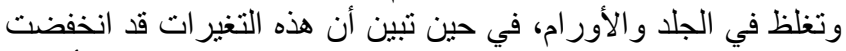

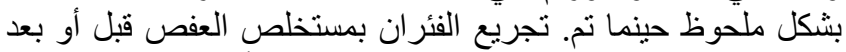

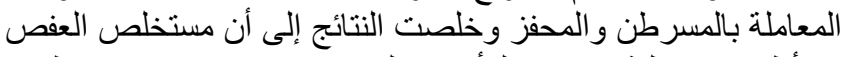

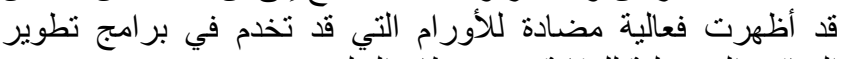
العقاقير المستقبلية للوقاية من سرطان الجلد. 